\title{
Writing amidst the Scribbles: The Role and Place of Writing in Ancient Maya Graffiti
}

Christophe Helmke ${ }^{1, *}$ and Jarosław Źrałka²

How to cite: Helmke, C and Źrałka, J. Writing Amidst the Scribbles: The Role and Place of Writing in Ancient Maya Graffiti. Papers from the Institute of Archaeology, 2021, 30(1): pp. 93-120. DOI: https://doi.org/10.14324/111.444.2041-9015.1287

Published: 15/11/2021

\section{Peer Review:}

This article has been peer reviewed through the journal's standard double-blind review.

\section{Copyright:}

(C) 2021, The Author(s). This is an Open Access article distributed under the terms of the Creative Commons Attribution License (CC-BY) $4.0 \mathrm{https}: / /$ creativecommons.org/licenses/by/4.0/, which permits unrestricted use, distribution and reproduction in any medium, provided the original author and source are credited • DOI: https://doi.org/10.14324/111.444.2041-9015.1287

\section{Open Access:}

Papers from the Institute of Archaeology is a peer-reviewed open access journal.

\footnotetext{
*Correspondence: cgbh@hum.ku.dk

${ }^{1}$ Department of Cross-Cultural and Religious Studies, University of Copenhagen

${ }^{2}$ Institute of Archaeology, Jagiellonian University
} 


\title{
CONFERENCE PROCEEDINGS: TIMELESS SPACES 2019*
}

\section{Writing amidst the Scribbles: The Role and Place of Writing in Ancient Maya Graffiti}

Christophe Helmke and Jarosław Źrałka

\begin{abstract}
The significant corpus of ancient Maya graffiti (c. 200 BC-AD 950) attests to the widespread practice of secondarily altering architectural surfaces during the course of their use. For the most part this corpus is highly figurative and includes a series of schematic elements that attest to their production by the hands of a variety of agents. As one of the largest corpora of graffiti from any early civilization, the figural representations include a wide array of themes. Some graffiti feature complex, narrative scenes that document important moments of ritual life of the ancient Maya. Almost paradoxically, amid the intricate and highly figurative scenes are hieroglyphic graffiti. What do these written graffiti record, and what is the degree of literacy that these attest to? This raises a series of interesting questions including whether written and figural graffiti were etched onto walls by the same individuals, or whether these represent different social segments each leaving their mark. From these observations follow a series of important ramifications as to authorship, the use of the built environment as well as the motivations behind the graffiti itself.
\end{abstract}

Keywords: Ancient Maya; Graffiti; Hieroglyphic Writing

\section{Introduction}

The expansive corpus of ancient Maya graffiti (c. 200 BC-AD 950) attests to the widespread practice of secondarily altering architectural surfaces during the course of their use. For the most part, this corpus is highly figurative and includes a series of schematic elements that attest to their production by the hands of a variety of agents, with differing degrees of spontaneity and skill. As one of the largest corpora of graffiti from any early civilization, these figural representations include a wide array of depictions of people, animals, supernatural entities, as well as diverse objects, the

"Timeless Spaces: Between Art, Politics, and Vandalism, a Seminar on Ancient and Modern Graffiti was a conference held at the Institute of Archaeology, University College London on the $16^{\text {th }}$ of March 2019, organised by Rosamund Fitzmaurice, Tia Watkins and loannis Nakas. This paper is part of the proceedings of that conference and have been edited by the organisers, with the support of Papers from the Institute of Archaeology. 
built environment, processions, triumphs and other activities such as the ballgame, and gladiatorial combats, to varying degrees of accomplishment and abstraction. Some graffiti feature complex, narrative scenes that document important moments of ritual life of the ancient Maya. So far, scholars have documented more than three thousand examples of graffiti from over ninety Maya sites located in Mexico, Guatemala, Belize as well as western El Salvador and Honduras (see Źrałka 2014) (Figure 1).

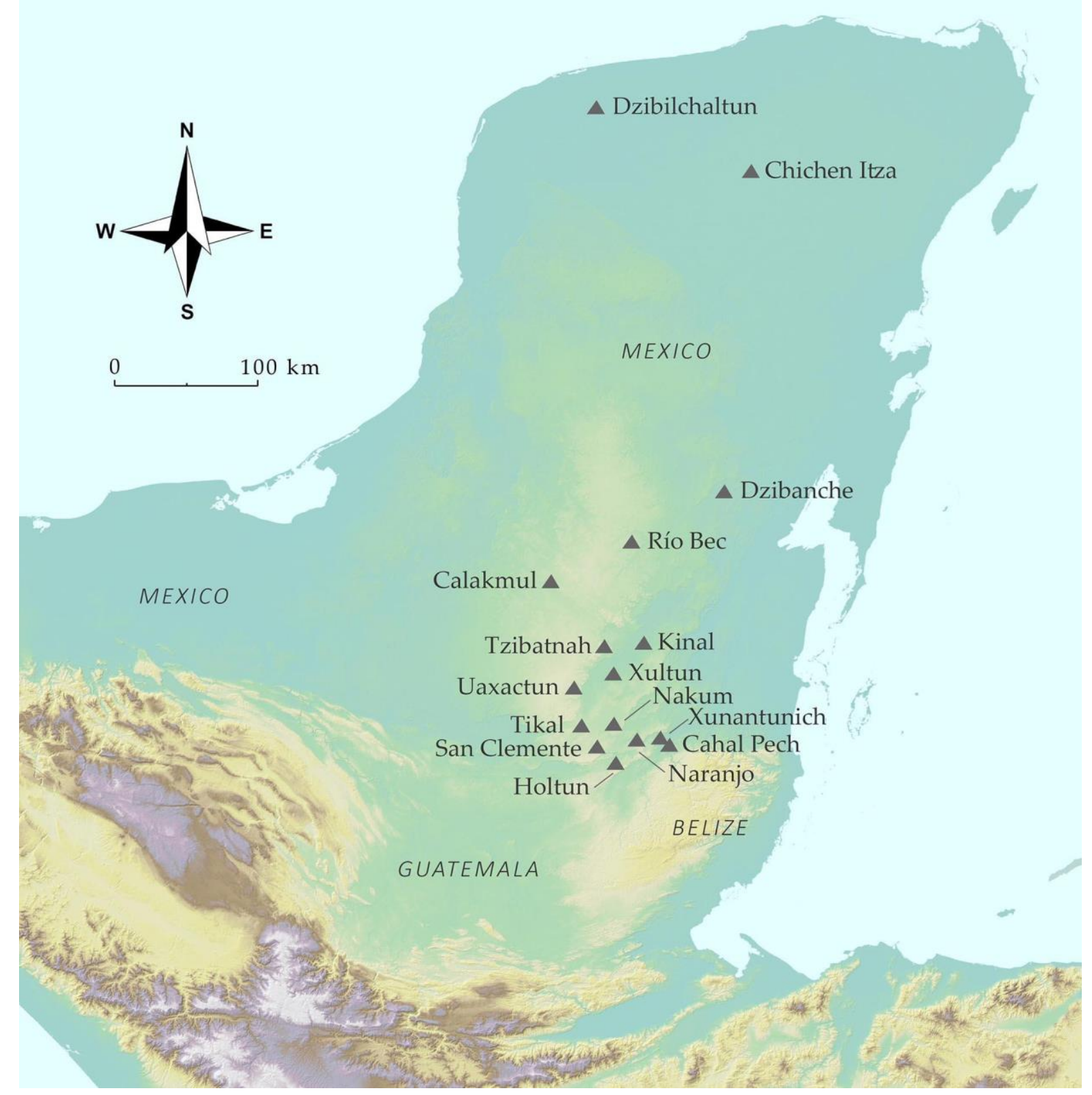

Figure 1: Map of the Maya area, showing the location of sites with glyphic graffiti that are mentioned in the text (map by C. Helmke). 
Almost paradoxically, amid the intricate and highly figurative scenes are hieroglyphic graffiti. However, these constitute a very small sub-set (c. $2 \%$ of the whole corpus of Maya graffiti), especially when compared to written graffiti of the Old World, particularly that known from ancient Egypt, Greece and the Roman Empire (Baird and Taylor 2011; Levin-Richardson 2019: 40-63; Navrátilová 2007; Peden 2001; Tanzer 1939; Varone 2002). In fact, a comparison to the Old World would see inscribed or painted inscriptions — some of these rather lengthy and viable texts as "graffiti", as long as these are secondary additions to the built environment or rock faces, even if these were written by priests accounting for the status of tombs, or overseers of royally mandated quarrying expeditions (see Peden 2001) (Figure 2).

This contrasts to the treatment of texts and writing in the New World where there is no such clear division between the primacy and ancillary nature of text. As such, glyphs co-occur in the broader swathe of graffiti, their unity brought about by the technique of their production (incising and painting), their secondary quality, and their thematic and contextual co-occurrence on plastered surfaces of the architectural environment. However, here a distinction can be drawn on the degree of accomplishment and content, since much graffiti that can be categorized as glyphic is in fact pseudoglyphic, meaning that it imitates the appearance of writing, but does not constitute legible nor viable text (see Calvin 2006). Pseudoglyphs aside, the remainder is an even smaller sub-set of glyphic graffiti that does constitute viable text, which were inscribed into the walls by literate individuals and it is on these texts that we will focus here. The distinction between the two types of glyphic graffiti raises interesting questions as to the degree of expertise and artistic accomplishment of the individuals who altered walls in antiquity with graffiti and would see divergent authorship as necessarily reflecting social standing and place in society.

However, an important caveat must be repeated from the onset, which is to consider the techniques employed in recording ancient Maya graffiti, in tandem with the artistic abilities of the individual(s) recording the graffiti, along with their degree of familiarity with ancient Maya iconography and conventions of figurative representations. As much of the draw of Classic Maya civilization is the great degree of artistic achievement, it is an unfortunate consequence that the graffiti and rock art 


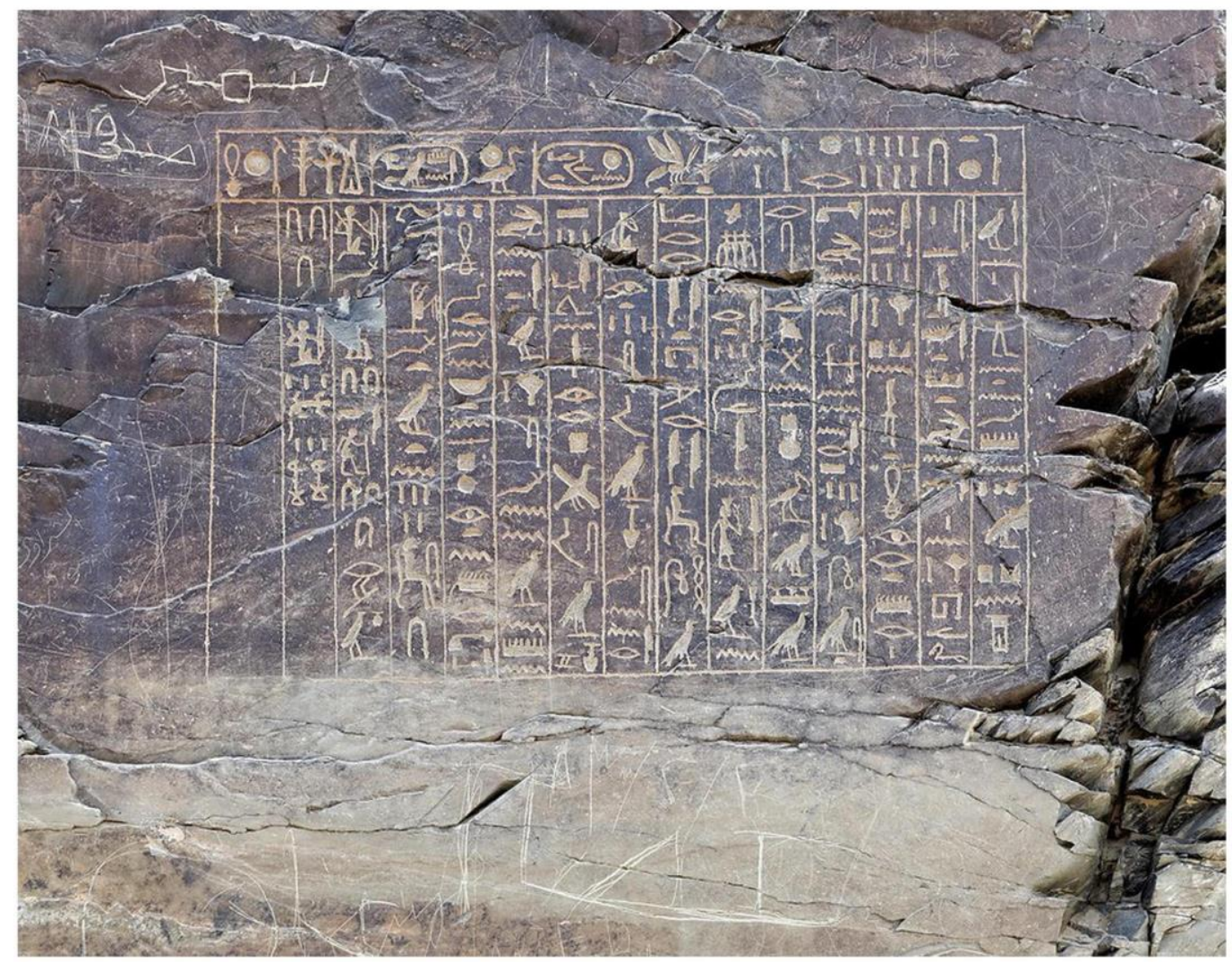

a

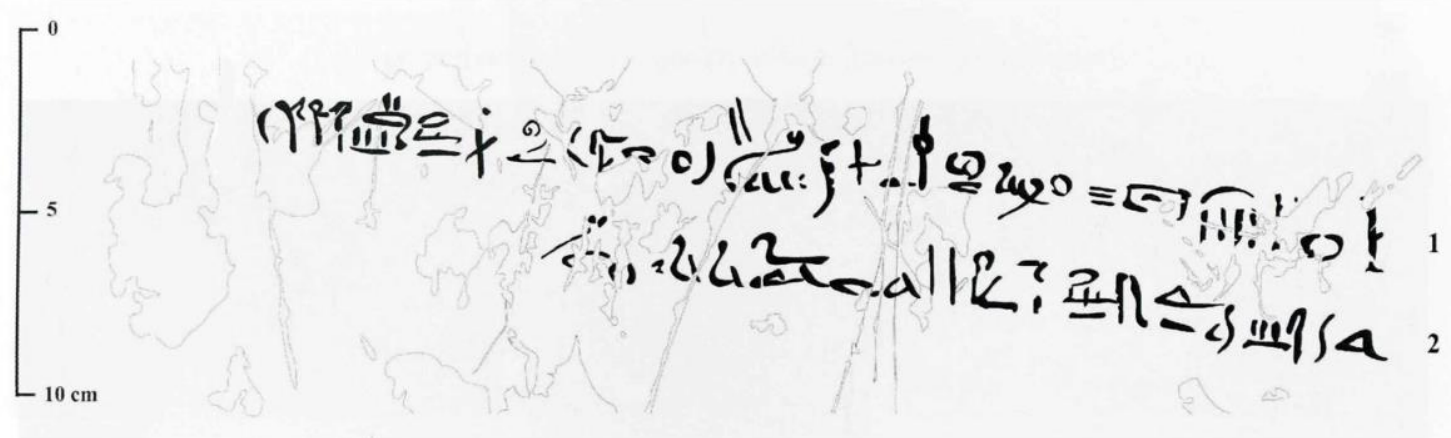

b

Figure 2: Formal pharaonic graffiti inscribed on a rock face and painted within a tomb: a) An inscription of the twelfth dynasty at Wadi Hammamat (photograph by S. Kaldov). b) Text recording the visit to the temple to Hathor at Asyut by the scribe Men during the reign of Amenhotep III (after Verhoeven 2012: Pl.1b). 


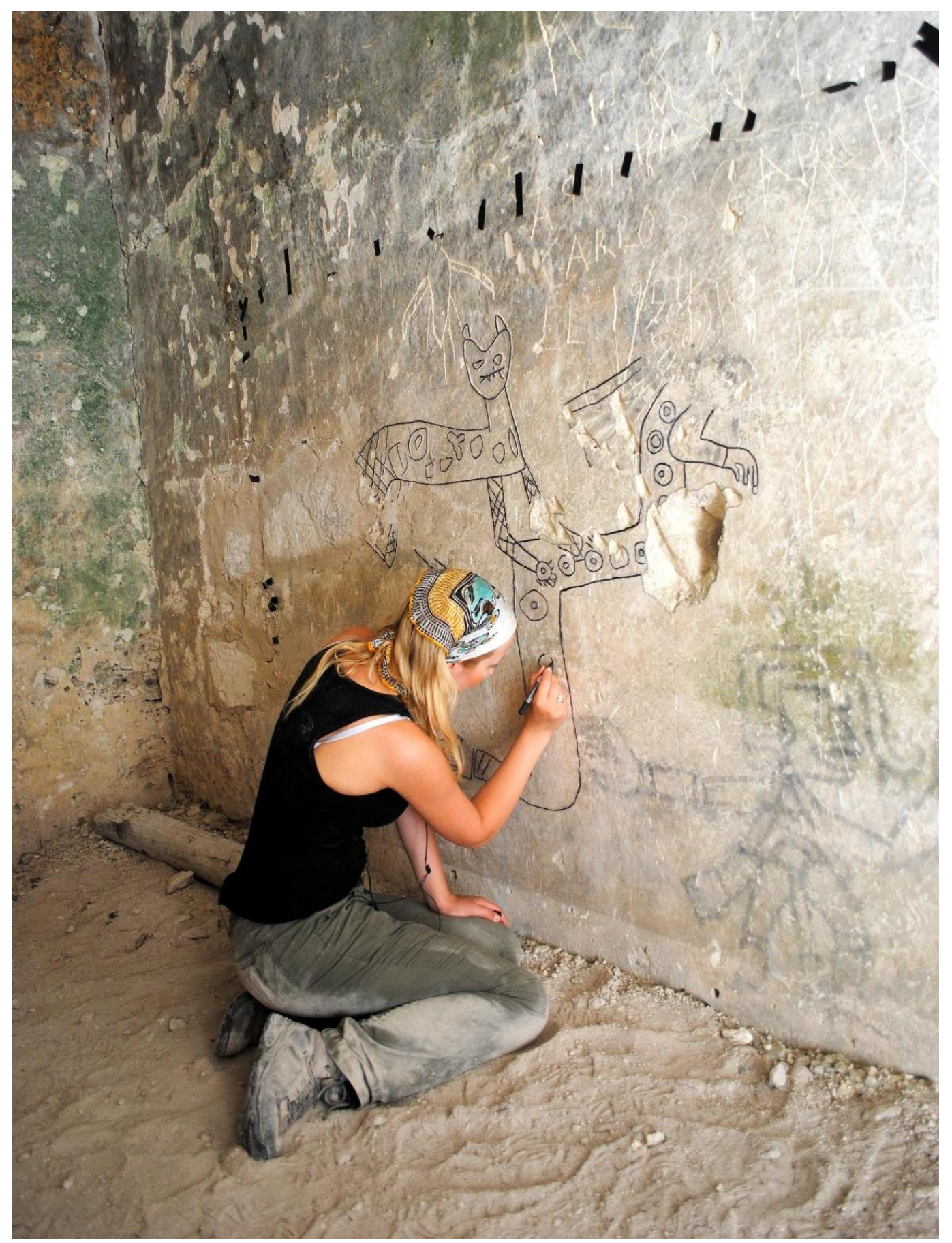

Figure 3: The modern documentation process, entailing the tracing of ancient Maya graffiti at the site of Nakum on acetate film (photograph by J. Źrałka).

produced by the very same civilization has been deemed to represent folk art, relegated by specialists to the sidelines of artistic production (e.g. Stone 2005). From this, it follows that the documentation of much of the graffiti produced by the ancient Maya has been entrusted to illustrators who are only partly informed as to the canons of Maya art. This has resulted in a rather disparate, partial and highly inadequate 
record of ancient Maya graffiti, a situation that is gravely exacerbated by the poor preservation of the faint incisions in the humid tropics. As a result - as with much archaeological inquiry - there are few opportunities to repeat the methodical documentation process of graffiti (Figure 3). On the contrary, on several occasions we have been able to witness the markedly dissimilar renditions of graffiti produced by varying modern illustrators. This is an observation that greatly complicates an already challenging undertaking, namely the interpretation of idiosyncratic, spontaneous and visceral artistic production. In fact, in more than one instance the schematicness and crudeness of the graffiti are not genuine features, but qualities introduced by the untrained illustrator.

These important observations in place we can now turn to the queries at hand. What do these written graffiti record and what is the degree of literacy that these texts attest to? This raises a series of interesting questions including whether written and figural graffiti complement one another, and whether these were etched onto walls by one and the same individuals, or whether these represent different social segments leaving their mark each in their own way, as has long been assumed. From these observations, follow a series of important ramifications as to authorship and social ascriptions, as well as considerations of contexts and the motivations for the production of graffiti in the first place (Patrois 2013; Vidal and Muñoz [eds.] 2009; see also Navarro-Castillo et al. 2018; Źrałka 2014). In this paper, we will address some of the above-mentioned questions and present illustrative examples of hieroglyphic graffiti, showing their content, context, meaning and significance for studies of ancient Maya civilization.

\section{Broader Context}

Most Maya graffiti were inscribed on plastered surfaces of masonry buildings, though we can also find examples that were created with the use of other techniques such as painting, printing, gouging, scratching, punctation, sketching with charcoal, or were rendered with the use of more than one technique and can thereby be called 'composite' graffiti (see Kampen 1978; Źrałka 2014: 87-94). Most Maya graffiti can be dated based on their archaeological and architectural contexts and stylistic content to the Classic period (3rd-8th centuries AD), corresponding to the apogee of Maya civilization. However, there are also few examples documented that both precede 
this period and date to the Preclassic and Protoclassic (c. 1000 BC-AD 250) as well as those that postdate the Classic florescence, which date to the Postclassic era (c. AD 950-1521) (Vidal and Muñoz 2009; Źrałka 2014: 186-190).

Before we move to the description and characterization of glyphic graffiti, we must first provide a definition of what the term "graffiti" encompasses. We define architectural graffiti as images or texts made on different surfaces - mostly interior walls of different buildings - that do not constitute original decoration or integral parts of these structures and places but can be treated as secondary additions. Besides, most Maya graffiti can be characterized by low stylistic quality and crudeness, and as such, they clearly differ from what is known as the formal high 'art' created under the patronage of Maya kings and nobles (see Kampen 1978; Mayer 2009; Źrałka 2014: 37-41). Thus, style and quality are also important aspects in defining graffiti, apart from archaeological and architectural contexts. Finally, we should remember the technique of execution. More than $90 \%$ of graffiti are examples made by incising/engraving, which is precisely what the term graffiti conveys at its root (graffiti [pl.] or graffito [sing.] stem from the Italian graffio which means 'a scratch' and by extension 'scribble').

Last but not least, we should also recall that graffiti were created on a variety of media. One popular group constitute ceramic graffiti that are a very poorly studied phenomenon among Maya scholars although these were created on the surfaces of vessels from the Preclassic to the Postclassic (Źrałka et al. 2018; for comparison see Lang 1974; Vanhove 2006). In other instances, polychromatic murals were the medium for incised graffito, as for instance on the dazzling murals of the Chiik Nahb pyramidal structure at Calakmul, where in a market scene a patron imbibes the beverage from a large blue-painted vase (Figure 4). The rim of the vase was secondarily inscribed with a graffito inscription of three glyphs, only the last of which survives, written yu-li, probably for $y$-uul, 'its atole' (a type of maize-gruel-like beverage) — revealing that the scene represents an atole stand (Martin 2012: 65). 


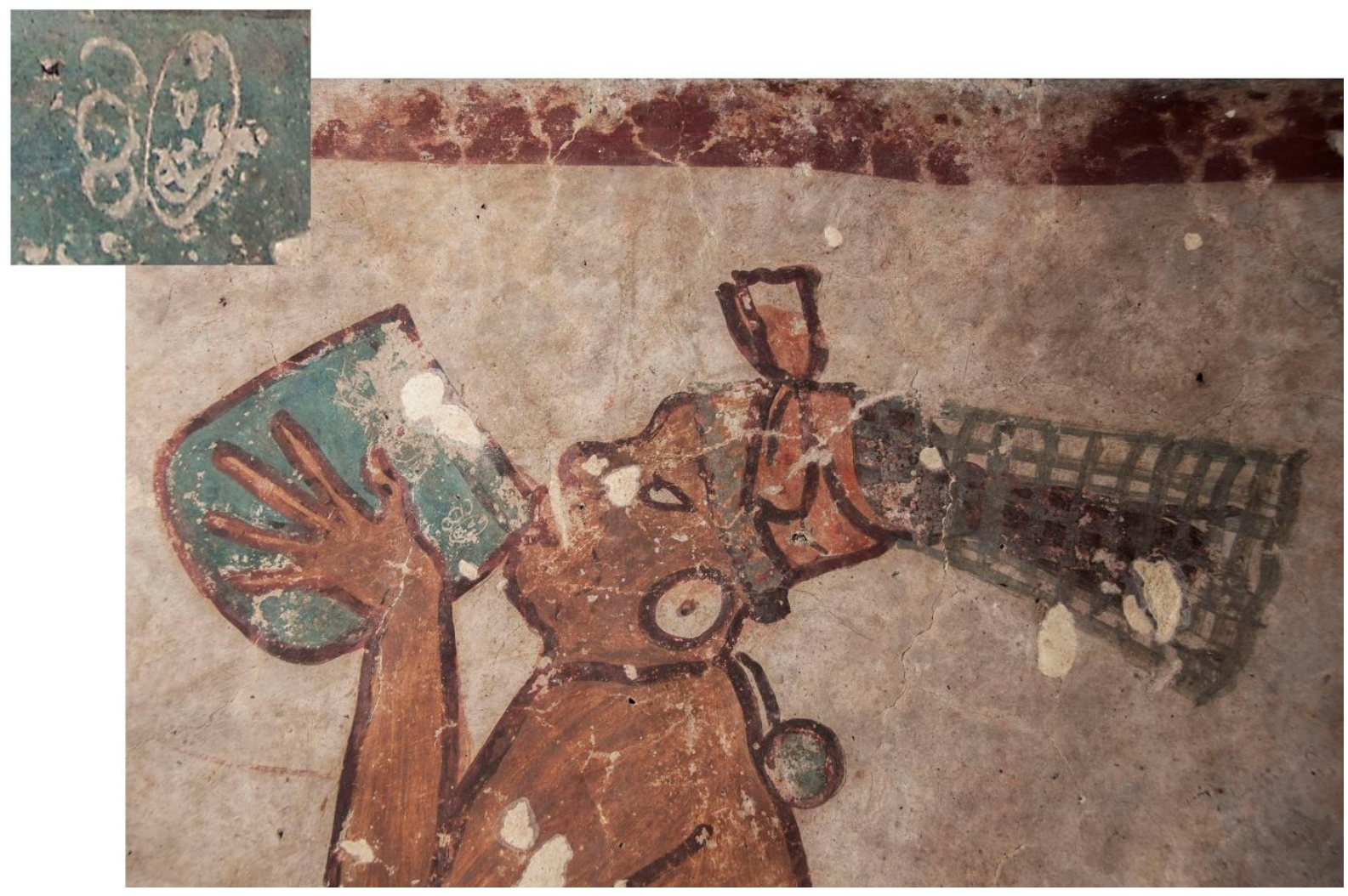

Figure 4: Detail of the market scene at Calakmul depicting the consumption of atole; the vase was secondarily inscribed with a small glyphic graffito along the rim (seen in the inset; photographs by R. Valencia Rivera - Proyecto Arqueológico Calakmul).

\section{Contents of Glyphic Graffiti}

To date, hieroglyphic graffiti have been documented at 16 Maya sites. These include Calakmul, Cahal Pech, Chichen Itza, Dzibanche, Dzibilchaltun, Holtun, Kinal, Nakum, Naranjo, Río Bec, San Clemente, Tikal, Tzibatnah, Uaxactun, Xultun, and Xunantunich (Aragón 2015; Blom 1928: Fig. 9.7; Callaghan et al. 2017: Figs. 8 and 10g; Cardona Caravantes et al. 2017: 320-321, 323; Kováč 2013; McCurdy et al. 2018; Orrego and Larios 1983; Saturno et al. 2012; Tokovinine and Fialko 2019; Trik and Kampen 1983; Zender and Skidmore 2012; Źrałka 2014; see also Fitzmaurice et al., this volume). In all, there are perhaps more than 60 graffiti that can be categorized as glyphic in substance. We can tentatively divide and classify glyphic graffiti into three broad categories: 1) pseudoglyphs and copies of viable texts, 2) calendrical notations, and 3) captions, as will be presented in turn, below. In addition to the glyphic notations that are of uncertain content and motivation, there are also lengthier clauses that are initiated with a Calendar Round notation and provide 
complete clauses. These are, however, exceedingly rare (for examples see Trik and Kampen 1983; Houston 2018). In most cases, we are dealing with short notations that record names, simple numbers or dates, and most stunningly, the extensive astronomical computations at Xultun (see Saturno et al. 2012; Zender and Skidmore 2012), and the comparable, albeit earlier, notations at Holtun (Cardona Caravantes et al. 2017: 320-321, 323; Callaghan et al. 2017: Figs. 8 \& 10g). Tikal clearly stands out in this group since it has both the largest corpus of documented graffiti for any one Maya site (see Orrego and Larios 1983; Trik and Kampen 1983; Webster 1963) and the largest collection of hieroglyphic graffiti (Źrałka 2014: 132, Table 1), suggesting that there is a proportionate correlation at play. This is to say that the vast majority of glyphic graffiti has been documented at Tikal (c. $90 \%$ ), with most of the remaining instances represented by one or two glyphic graffiti for a given site. Exceptions to this are sites where three or more graffiti are known, including Nakum, Tzibatnah, Xultun and Xunantunich.

At Tikal, most glyphic graffiti are found in residential, palatial constructions inhabited by the most important members of the local court, such as Maler's Palace, the Bat Palace and the large residential complex of Group G (Strs. 5E-55-2 and 5E-58) (Orrego and Larios 1983; Trik and Kampen 1983). Glyphic graffiti were also documented, though in much lower frequency, inside temples, such as Structures 5D-23, 5D-33-2, 5C-49, as well as within the emblematic Temples II and VI. In this corpus, we can find some 15 examples of Calendar Round dates or other calendrical notations. The second category in terms of ubiquity are the graffiti that provide captions, presumably serving to record the names of the individuals who wrote these segments. In this sense, these are merely notations of the 'Kilroy was here' type (see Bates 2014).

\section{Copies of Viable Texts}

To start, we would like to briefly mention a group of graffiti which do not represent true, viable hieroglyphic texts but imitations or copies of actual inscriptions or carved monuments. To this group we can ascribe graffiti from Nakum, Tikal and Chichen Itza that feature what look like carved monuments covered by texts or even pages of codices (Figure 5). An interesting graffito from Las Monjas group at Chichen Itza, depicts a chaotic set of geometric-like representations, that may in fact be a partial copy of a true, official inscription carved on the lintel from this architectural complex 
(located in East Wing). It seems that the author of this graffito might have been a scribe familiar with the principles of Maya writing although he changed the order of glyphs he copied (see Boot 2013).

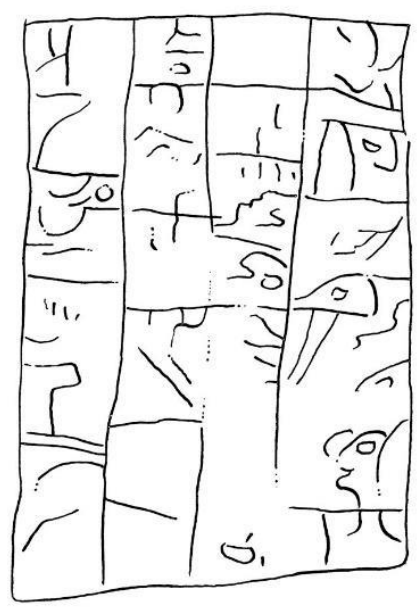

a

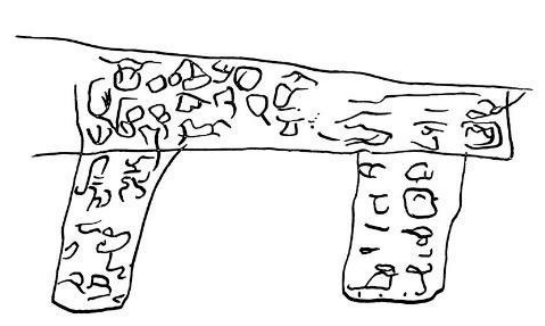

C
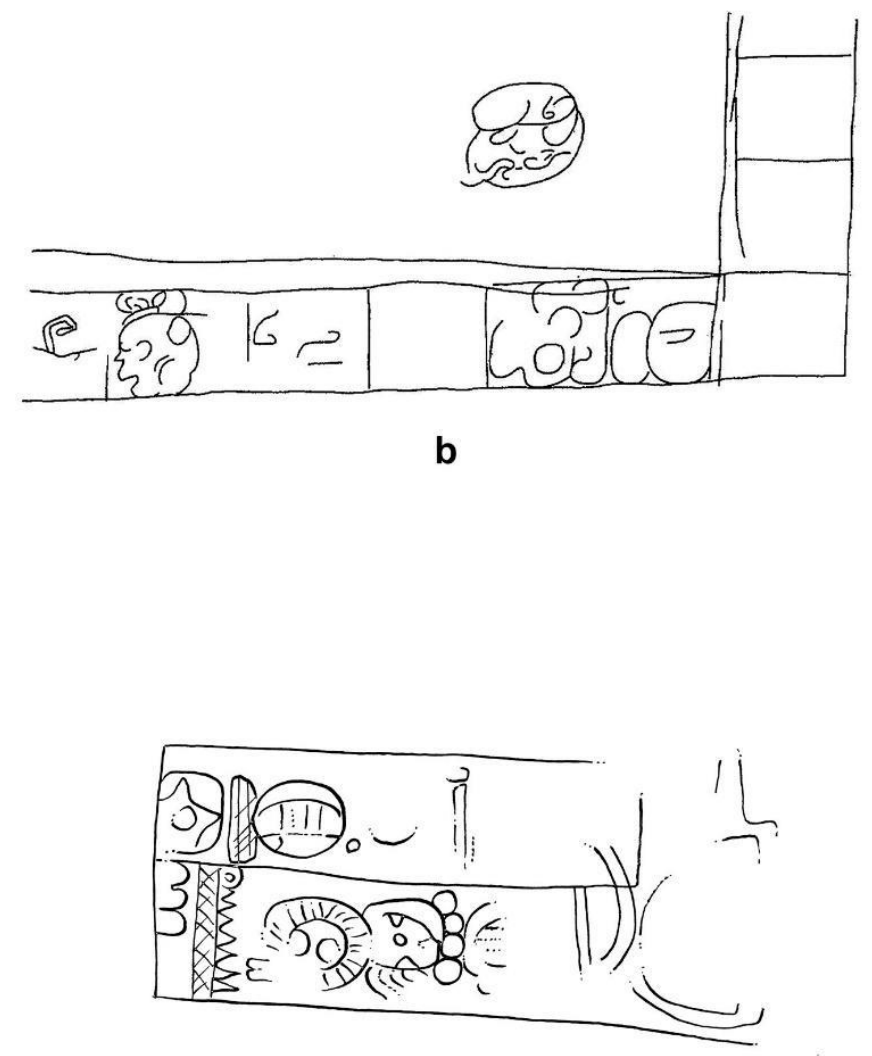

d

Figure 5: Copies of viable texts in graffiti. a) Tikal, Maler's Palace, Room 9, south wall (drawing by Ch. Helmke, after Trik and Kampen 1983: Fig. 73); b) Bat Palace, Room 11, north wall (adapted by J. Źrałka, after Trik and Kampen 1983: Fig. 28c). c) Nakum, Str. Y, Room 3, south wall (drawing by C. Helmke, after Calderón 2008 et al. 2004: Fig. 110). d) Tzibatnah, Casa de las Pinturas (drawing by C. Helmke, after Kováč 2013: Fig. III-31).

There are also graffiti that feature stelae at Tikal and Río Bec (see Trik and Kampen 1983: Fig. 46). One interesting example from Structure 5N2 (Room F) at Río Bec A features a complex narrative scene that represents a possible stela dedication (see Patrois and Nondédéo 2009: Fig. 20f); we see several individuals standing close to a two-tiered construction in front of which is a probable stela that features the 
schematic representation of a lord (Patrois and Nondédéo 2009: 54, 56). The famous ballcourt scene graffiti from Tikal Structure 5D-43 (see Trik and Kampem 1983: Fig. 46) also features a set of stela and altar standing in front of a low pyramid. The size of these two monuments is very small and the author of this graffito was not able to show details of the relief; and instead chose to cover the stela with a crosshatched design. Within Structure Y at Nakum there is also a possible representation of a throne that seems to be covered with schematic depictions of glyphic texts (see Źrałka 2014: Plate 46j) (Figure 5c). Some graffiti at Tikal may even depict pages of codices with the characteristic division of pages, with iconographic fields delineated by glyphic bands (Figure 5a-b). One graffito from Casa the las Pinturas at Tzibatnah may also fit the same category (Figure 5d) (Kováč 2013: Fig III-31).

\section{Calendrical Notations}

By far the majority of glyphic graffiti are calendrical notations, either recording sole days in the Tzolkin or Calendar Round dates recording combinations of the Tzolkin and Haab calendars, as well as isolated numbers or numerical arrays of computational or astronomical significance. The dates either record important event dates such as those of Period Endings, which were observed by great rituals and pageantry or alternatively these record historical dates, most likely coincident with, or at least temporally proximate to the realization of the graffiti itself.

At Tikal, the largest number of glyphic graffiti involve calendrical dates, either partial or complete Calendar Rounds and if the latter, then these often head shorter clauses, suggesting that these once recorded viable historical dates. Unfortunately, owing to erosion and the accuracy of the documentation, only parts of most dates can be discerned (see Trik and Kampen 1983; Źrałka 2014: Plates 44-45). The historical character of at least one Calendar Round date is confirmed by a graffiti of Str. 5C49, the talud-tablero temple of the Mundo Perdido group, which records the historic date 6 K'an 7 Pax (Figure 6a), quite possibly corresponding to an event in AD 697 (Houston 2018). A solitary date painted within the second chamber of the roofcomb of Temple II records 8-AJAW, probably commemorates the Period-Ending date 9.13.0.0.0, corresponding to AD 692 during the reign of Jasaw Chan K'awiil I (Figure 6b) (see Źrałka 2014: Plate 44o; Martin and Grube 2000: 44-47). Likewise a simple 2-AJAW notation within the Group G palace (Structure 5E-55-2) may refer to the Period-Ending of 9.16.0.0.0 of AD 751 (Figure 6c), likely at the end of the reign of 


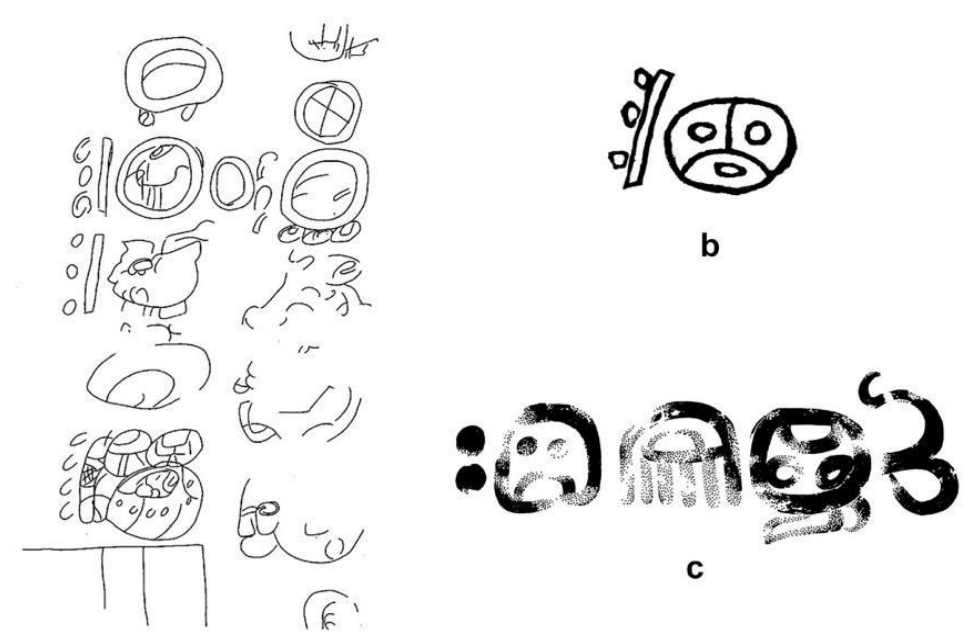

a

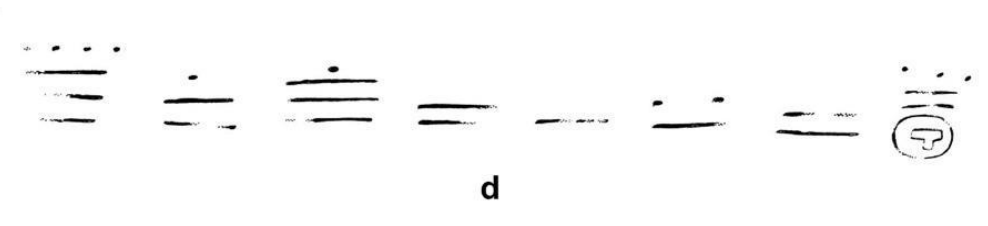

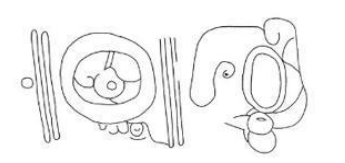

e

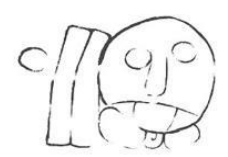

f

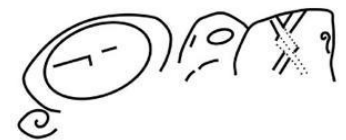

g

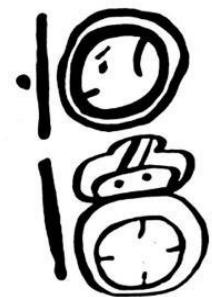

h

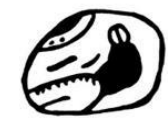

Figure 6: Calendrical notations at various Maya sites. a) Tikal, Str. 5C-49, Room 1, multi-clause text headed by the Calendar Round date 6 K'an 7 Pax (after Trik and Kampen 1983: Fig. 29c); b) Temple II, roofcomb, Chamber 2, Tzolkin date 8 Ajaw (after Trik and Kampen 1983: Fig. 40c); Str. 5E-55-2 ${ }^{\text {nd }}$ c) painted text featuring the date 2 Ajaw (drawing by C. Helmke); d) numeric array closed by the Tzolkin date 13 Ik' (drawing by C. Helmke). e) Nakum, Str. E, Chamber 1, Calendar Round date 11 Manik 10 Xul (drawing by J. Olko). f) Xunantunich, Str. A-13, Room 7, Tzolkin date 11 Ajaw (drawing by C. Helmke); g) Tzibatnah, Casa de las Pinturas, Calendar Round date (drawing by M. Kováč, after Kováč 2013: III-33); h) Dzibilchaltun, Str. 1-sub, painted Calendar Round date 6 Men 5 Yaxk'in (drawing by I. Jurkiewicz after Andrews and Andrews 1980: Fig. 112). 
Yik'in Chan K'awiil (see Aragón 2015: 111-112; Martin and Grube 2000: 48-50). Surprisingly, in the penultimate phase of Str. 5E-55-2nd one of the walls was decorated with a series of muddied handprints, with one configuration deliberately made to resemble a simple calendrical ajaw glyph (Figure 7). One of the more surprising graffiti within the same penultimate structure is a horizontal numerical array, preceding a solitary Tzolkin date 13-IK', that can be transliterated as 19.11.16.10.5.7.10 (Aragón 2015: 110; Orrego and Larios 1983: 100, Plate 4g) (Figure 6d). Although the exact nature of this computational array remains unknown it is highly reminiscent of those documented at Xultun, each paired with single Tzolkin dates, as has been analysed in detail elsewhere (Bricker and Bricker 2017; Saturno et al. 2012; Zender and Skidmore 2012). Precursors to these calendrical arrays, including records of lunar periods have recently been found at the site of Holtun within Structure F2-sub-1 (a Late Preclassic sanctuary associated with an E Group) in contexts dated to the Protoclassic, making these some of the earliest astronomical notations known to date (see Cardona Caravantes et al. 2017:320-321, 323; Callaghan et al. 2017: Fig. 8, 10g). One of these (Graffito F), records the numeral '5' above a moon sign, the whole notation closed by a Tzolkin date initiated by the coefficient '4' (Figure 7b). The other (Graffito H), records '15' followed by a head-variant logogram, above a wing sign - possibly of verbal function — with what may be an inverted numeral ' 6 ' and a moon sign at the end (Figure 7c). The similarities between the graffiti of Tikal, Xultun and Holtun, further suggest that day keepers conducted their craft at these locations, jotting notes on the walls of their workplace (see Saturno et al. 2017).

Nakum, which is located just $23 \mathrm{~km}$ southeast of Tikal, features a large collection of graffiti, with a few examples of glyphic graffiti (Hermes et al. 2001; Źrałka and Hermes 2009). These include simple numerical notations and one Calendar Round date. The first of these was incised on the eastern wall of the main chamber of the enormous Structure $\mathrm{E}$ that consists of a large pyramidal base topped by three rooms. It is without a doubt a Calendar Round date, most probably read as 11 Manik $10 \mathrm{Xul}$ (Figure 6e) (Hermes et al. 2001: 60-61). Since such a Calendar Round date repeats every 52 years in the permutations of the Mesoamerican calendars, it is hard to connect it to any specific year in Gregorian calendar - though based on the architectural context of this graffito we can situate its rendition in the period between 

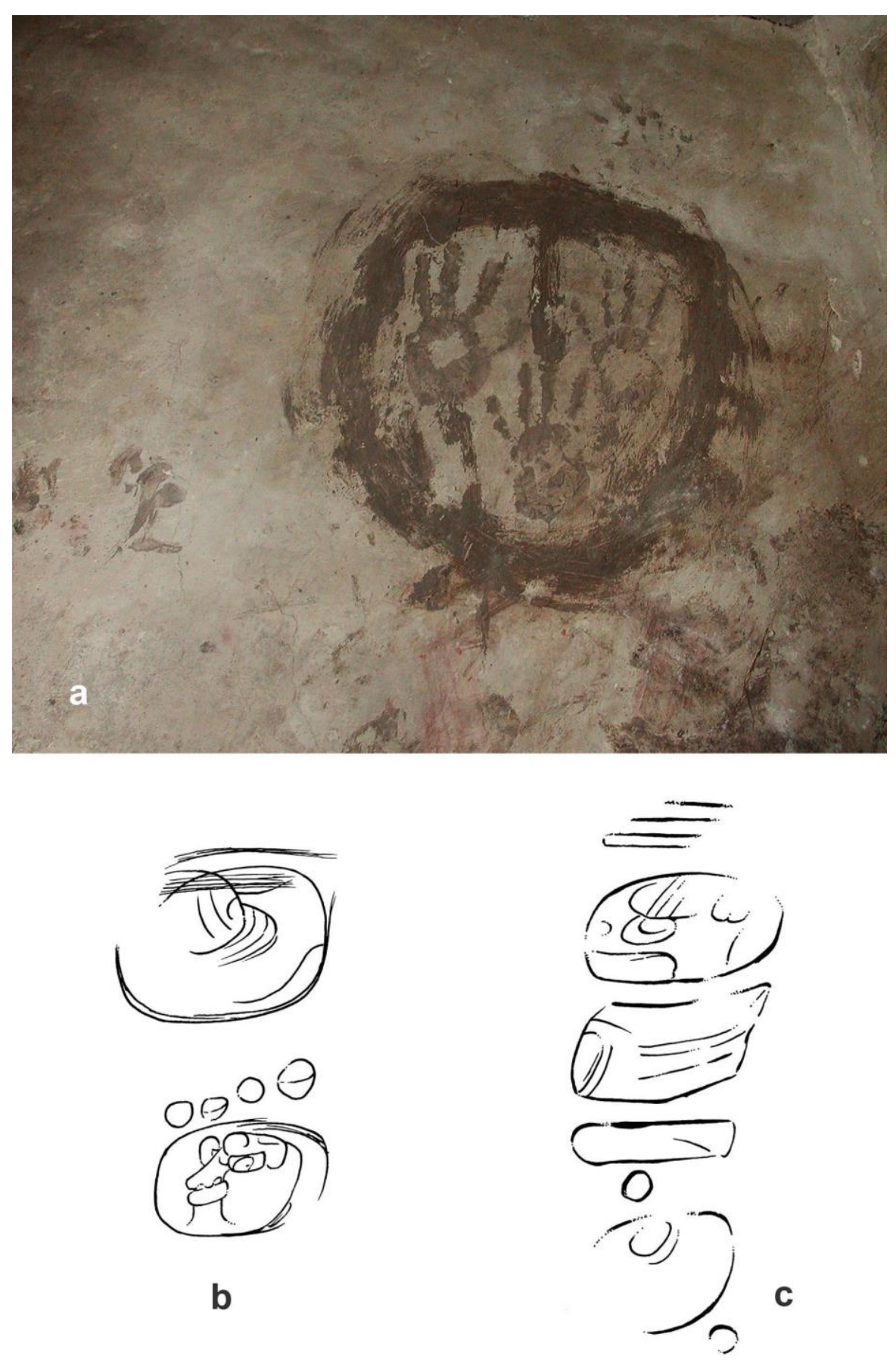

Figure 7: a) Tikal, Str. 5E-55-2 ${ }^{\text {nd }}$, stylised Ajaw glyph shaped with muddied handprints (photograph by G. Ricci, courtesy of B. Hermes). Holtun, Str. F2-sub, graffiti dated to the proto-Classic: b) Graffito F, with lunar notation and Tzolkin date (drawing by C. Helmke, after a drawing by M. Clarke, in Cardona Caravantes et al. 2017: Ill. 268), c) Graffito H, lunar notational array (drawing by C. Helmke, after a photograph by M. Callaghan, courtesy of the Holtun Archaeological Project). 
the eighth and ninth centuries AD. Two other glyphic graffiti from Nakum are just simple numerical notations: inside the interior of one of rooms of the palatial structure (N-60-61) we can find two or three numbers inscribed on the wall: 6.3 (possibly corresponding to 123 in decimal numerals) or alternatively 1.5.3 (number 463), meanwhile inside the eastern chamber of Structure $G$, the number 3 accompanied with a large square-like element was painted on the wall (Źrałka 2014: Plate $46 \mathrm{~b}$ and 461$)$. Whether these numbers refer to some calendrical notations or calculations of economic character remains an open question.

Other Peten sites, such as Tzibatnah, also feature glyphic graffiti similar in its content to the examples described above. Milan Kováč and his team have documented in one of the excavated structures at Tzibatnah (Casa de las Pinturas) a Calendar Round date (involving what may be the Day Sign Ik' with the seating of Pop, suggesting a New Year's date (Figure 6g), and one chronological/calendric notation where the haab ('year'), k'in ('day') and the Day Sign Lamat remain visible (Figure 5d) (Kováč 2013: Fig. III-31 \& 33).

Recent excavations at Xunantunich have identified additional examples of graffiti, notably in the rooms of the range structure (Str. A-13) in the northern palace of the site (see Fitzmaurice et al., this volume). In this case, the glyphic graffiti consists of a single calendrical notation in the Tzolkin calendar, written 11-AJAW incised into the surface of the bench of Room 7 (see Watkins et al. 2018) (Figure 6f). Given the brevity of the date and the use of the day sign Ajaw, it seems probable that this records an important Period Ending date, perhaps 9.18.0.0.0, corresponding to AD 790 (Watkins et al. 2018: 340, Fig. 5).

Farther north, at Dzibilchaltun, on the north wall of the southern corridor of the buried Str. 1-sub we see the black-painted Calendar Round date 6 Men 5 Yaxk'in, followed by what may be an abbreviated verbal expression (Figure 6h) (Andrews and Andrews 1980: Fig. 112). Although legible, the date follows an irregular pattern wherein the combination of Tzolkin and Haab are actually incompatible (see MacLeod and Stone 1995: 157-162). Explanations for such non-standard dates remain wanting, but may refer to spans of time, for events that took place over several days (Helmke 2009: 167-168). 


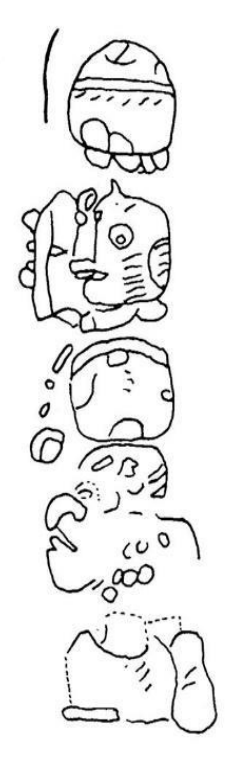

a
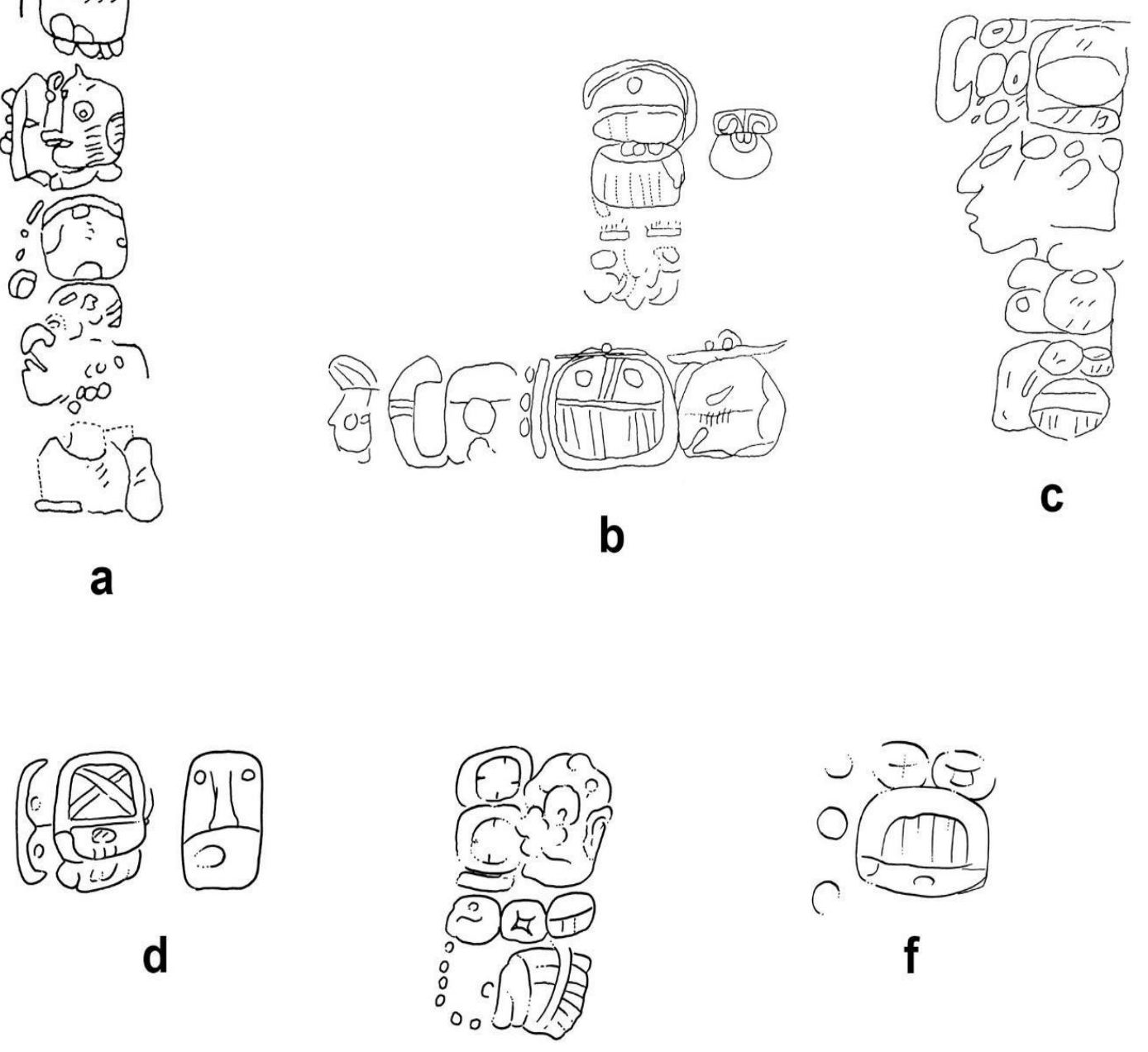

e

Figure 8: Autographs and related expressions at Tikal and Tzibatnah. a) Tikal, Str. 5D-65, caption headed by u-baah (adapted by J. Źrałka, after Webster 1963: Fig. 10), b) Str. 5D-33-2 nd, autograph including wo'oj 'glyph' (adapted by J. Źrałka, after Webster 1963: Fig. 20); c) Temple II, Room 1, possible female nominal caption (after Trik and Kampen 1983: Fig. 32a); d) Temple II, Room 2, captive statement epithet (drawing by C. Helmke, after Trik and Kampen 1983: 37); e) Tikal graffito from Tikal Structure 5E-55-2 ${ }^{\text {nd }}$ that represents the prestigious title of local kings: ochk' in kalomte' k'ubul Mutu'l ajaw (drawing by C. Helmke, after Orrego and Larios 1983: Pl. 3D). f) Tzibatnah, Casa de las Pinturas, regional title (drawing by C. Helmke, after Kováč 2013: Fig. III-117). 

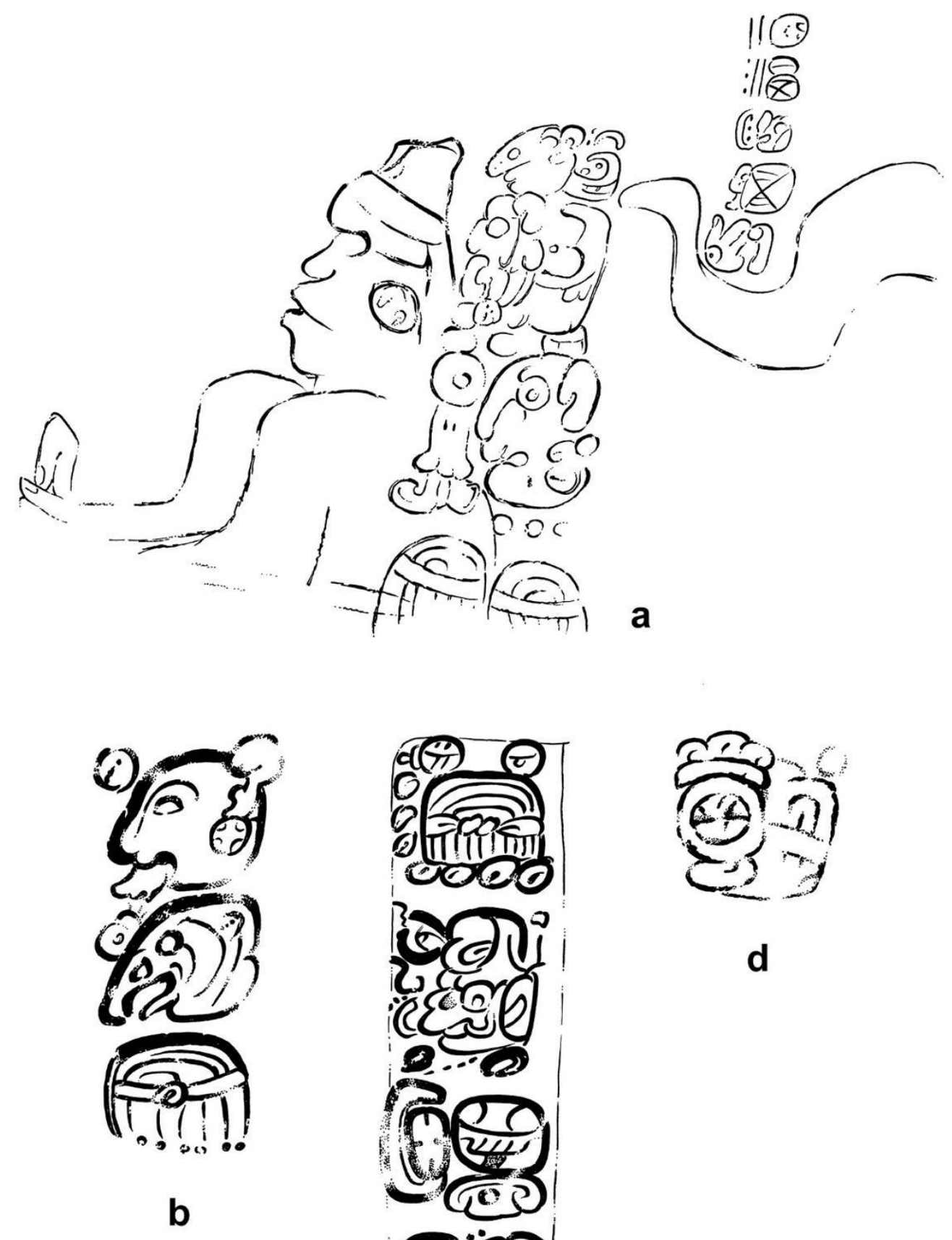

d

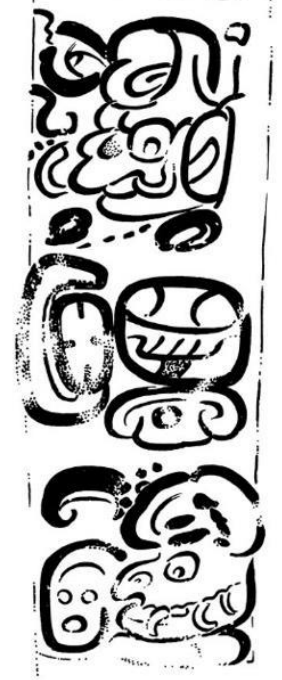

C

Figure 9: Further autographs at Tikal and Xunantunich. a) Tikal, Str. 5E-55-2 $2^{\text {nd }}$, scene with autograph and caption; b) painted autograph; c) painted autograph with idiosyncratic reading order. d) Xunantunich, Str. A5-2 $2^{\text {nd }}$, incised titular reference (drawings by C. Helmke). 


\section{Captions and Autographs}

Aside from the calendrical thrust of much glyphic graffiti are a series of short texts that serve to record names. These either accompany figurative scenes and can thereby be qualified to function as captions to particular scenes or vignettes, or alternatively a given graffito names the individual who has rendered the text, serving as something akin to a tag or autograph. At Tikal, for instance, in the Maler Palace (Str. 5D-65) we see one graffito that is headed by the expression $u$-baab 'it is his self, followed by the names and titles of the author (Figure 8a). In another, albeit indistinct text, in Room 2 of Str. 5D-33-2nd, we see what may be wo-ja, for wo'oj, 'glyph', presumably remarking that the caption self-referentially names author of the glyphs themselves (Figure 8b). Another reference is seen in Room 2 of Temple II, where the autograph is recorded as u-CHAN-na / SAK? presumably for ucha'n saak, 'the captor of Saak' (Figure 8d), providing an individual's captive statement-wherein the name of a captive was included into a titular name phrase (Źrałka 2014: Plate 44i; see also Helmke 2020: 37-39).

The Tikal Emblem Glyph can be also found in comparable contexts, once inside Temple II, where this prestigious title is preceded by what appear to be the names of an important person, apparently a local woman (u-ti-?-t'o / CHIT?-ta / IX-? / ??-ba / K'UH-MUT-AJAW) (Figure 8c) (Trik and Kampen 1983: Fig. 32a; Źrałka 2014: Plate 44h). Another example of the Tikal Emblem Glyph comes from the penultimate building (Str. 5E-55-2nd) within the palatial Group G where the prestigious title of Tikal kings is written in full as ocbk'in kalomte' k'ubul mutu'l ajaw (OCH-K'IN-ni-KALOM / K'UH-MUT-AJAW) or 'western emperor, divine king of 'Tikal' (Figure 8e) ('́rałka 2014: Fig. 45q). Could this have been written, in a moment of solitude, by the supreme monarch himself? Inside the same building, we have two additional glyphic sequences, each closing with a representation of Tikal Emblem Glyph. In the first instance the autograph reads ubaab ti mutu'l (u-BAH / ti / MUT) presumably using the main sign of the Emblem Glyph for its toponymic function, as 'it is his self at Tikal' (Figure 9b). In the other instance, the caption labels the depiction of a corpulent man and closes with a double reference to the Emblem Glyph (Figure 9a). What may be a secondary caption is presented in even smaller format, slightly off to the side (see Aragón 2015: 109). The name in question here can only be partly transcribed but ends with JUN-BALAM-ma, for junn bablam, or 'One Jaguar'. An analogous name, of a priestly ajk'ubu'n 'pontifex', is also recorded 
on a contemporaneous engraved conch shell (see Schele and Miller 1986: 155, Plate 59a), although whether this is the same individual or a namesake is unknown. Finally, a painted graffito records an idiosyncratic autograph, since the column of glyphs is intended to be read from bottom to top as yanabil yik', in chan k'awiil k'ubul mutu'l ajaw (ya-na-bi-li / yi[K'IN]-CHAN-na / K'AWIL-la / K'UH-MUT-la-AJAW) (Figure 9c). This sequence informs us that the tag is that of the anab of the 27th king of Tikal, Yik'in Chan K'awiil, who ruled from AD 734 until sometime in the mideighth century (Martin and Grube 2000: 48-50). The key here is to resolve precisely what the title anab refers to, but it appears to have been a title for artisans, perhaps for sculptors and masons. The same title is seen in another graffito in the same building, where a new anab is said to be the companion (yi[ta]-ji) of yet another (Źrałka 2014: Plate 44b).

At Tzibatnah although we do not see an Emblem Glyph we also see a local title of some importance, read ux baab [te'] ajaw 'lord of three years' (Figure 8f) (Kováč 2013: Fig. III-36; Źrałka 2014: Plate 46f). The title is known predominantly from ceramics of north-eastern Peten, which were produced for the rulers of Río Azul. As such, given the relative proximity of Tzibatnah to this dynastic centre we can see that there is a connection between the sites that is reiterated by the appearance of this dynastic title in the graffiti of the site.

Recently, a set of glyphic graffiti has been also documented at Naranjo. Excavations within the imposing Central Acropolis, revealed one of the early buildings, engulfed by later architectural growth. This building was attributed the field designation of Aurora and is embellished with elaborate modelled friezes on its northern and southern facades, depicting a mountainous supernatural realm populated by an imposing hummingbird deity — one of the major tutelary deities of Naranjo (Tokovinine and Fialko 2019). The Aurora structure was constructed during the reign of Naranjo's longest reigning king nicknamed “Aj Wosal” (AD 546-615+) (Martin and Grube 2000: 71-72). Inside the Aurora structure is a striking scene depicting a torch-wielding anthropomorphic figure in the guise of a deity, standing before a large and oddly elongated deer, in a lying posture, that has been speared in the hindquarter (Figure 10a). The scene has some evident correspondences with iconography in the Dresden Codex, and with two scenes in particular. One is within the Venus tables (p. [50] - 47) that depicts a deer that has been shot in the hindquarter and another in the 


\section{Mint}

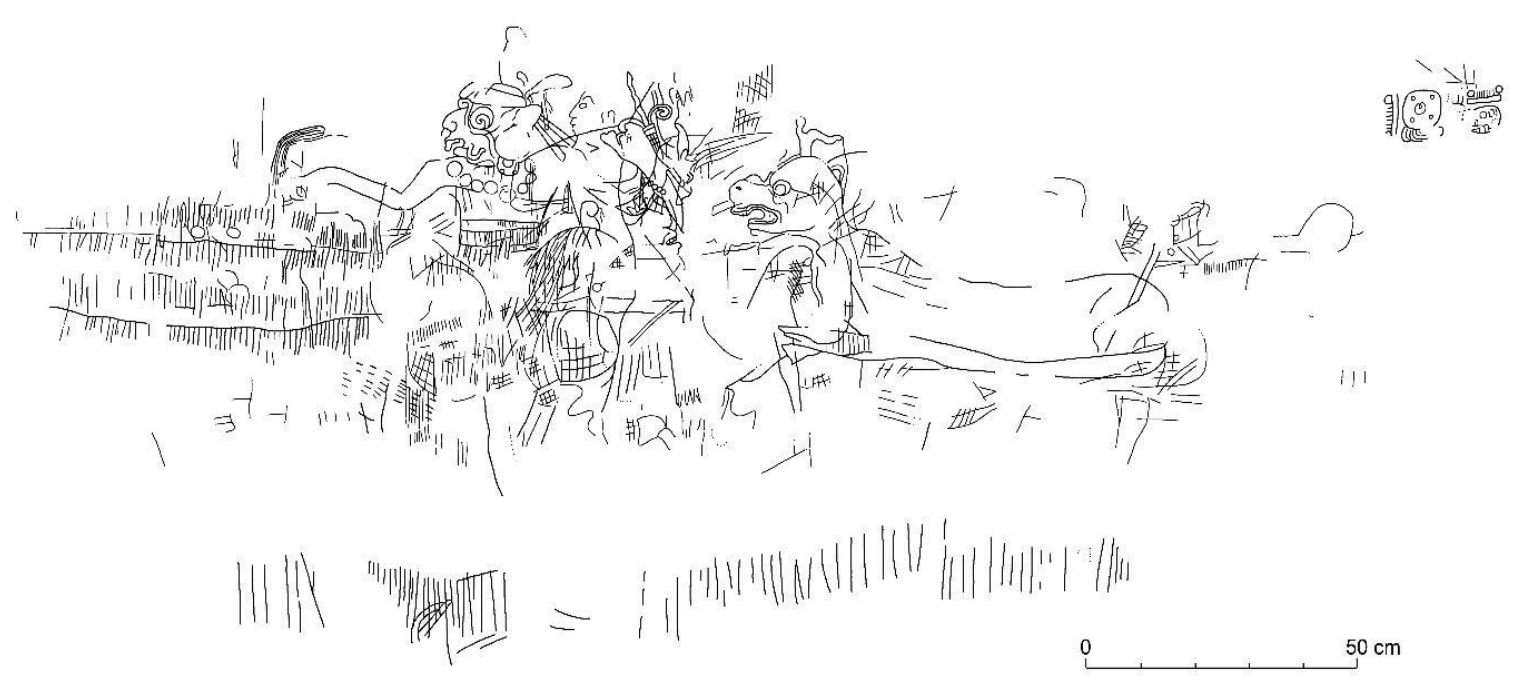

a

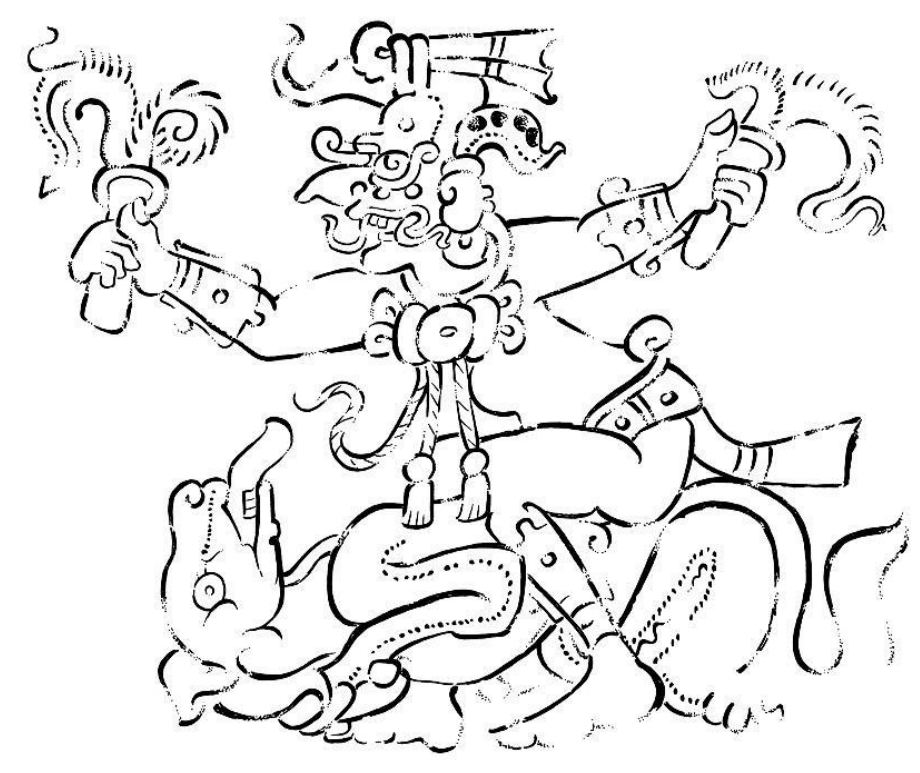

b

Figure 10: a) Naranjo, Aurora, graffiti scene of speared deer with torch-wielding deity and glyphic caption (drawing by A. Tokovinine, after Tokovinine and Fialko 2019: Fig. 9a). b) Excerpt from the Dresden Codex showing an analogous scene with a torch-wielding Chaak subduing a deer (p. [48] - 45) (drawing by C. Helmke). 
Chaak pages - two pages before - arranged according to the cardinal directions, wherein a torch-wielding thunder deity subdues a deer (p. [48] - 45) (Figure 10b). These equivalences suggest that the graffiti scene at Naranjo is much more than just a supernatural scene, but one with overt calendrical and augural overtones. A series of small notches embellish the scene, which occur in numerical sets that are consistent with calendrical calculations pertaining to the Tzolkin calendar and lunar interstices (Tokovinine and Fialko 2019: 830). Significantly, a small glyphic graffito has been added to the edge of the scene that can be read as aj-bin ti aj-k'uh (a-bi-ni / ti-a-K'UH). Whereas the initial segment is semantically unclear, it may refer to the deer as 'the elongated one', with the closing caption adding the priestly title ajk' 'ub 'he of the deity'. The same title occurs once more in another graffito in the same structure and here it closes with an autograph naming the priest. As such, we can conclude that the pontifex of the tutelary deity of Naranjo, lived and worked within the quarters of Aurora, where he kept track of day-counts for calendrical computations.

On-going excavations at Xunantunich, have brought to light a series of highly decorated rooms in a buried and penultimate phase of the Castillo (Str. A5-2nd), the imposing palatial group that dominates the southern end of the monumental epicentre of the site. In Str. A-5-2nd the walls are highly embellished with a bewildering collection of graffiti encompassing a wide array of themes and degrees of accomplishment. The diversity and extent of this assemblage are equally significant, but it is their good preservation and that these date to an earlier, sealed phase of construction that makes these all the more remarkable. Analyses of this substantial assemblage are still underway but preliminary analyses suggest that these rooms may have been reserved for acolytes trained in the scribal arts, given the many profiles and forms that are repeated, suggesting practice, for both figurative and glyphic elements (McCurdy et al. 2018; McCurdy and Brown in press). Most telling is perhaps a solitary glyph written [i]tz'a-ta, for itz'at a title typically understood as 'wiseman' but in this context probably refers to the instructor of the scribal school (McCurdy et al. 2018: 191, Fig. 5d) (Figure 9d).

Several texts that appear as graffiti are more complex and consist of longer inscriptions. In addition to the examples from Tikal, is a glyphic text found in the central room, on the wall above what appears to have been the royal throne in the 
palace at Cahal Pech (Structure A-1) (Figure 11). This text refers to an enthronement (literally CHUM / ti-AJAW-le, 'seating into kingship' within the WAY or 'room'), presumably of the local monarch and later, at the end of another clause text we can discern titular elements that belong to the nobility of Naranjo (i.e. Wak Kabnal Winik 'person of the Wak Kab-place' and Sak Chunve'n 'pure artisan'); suggesting the involvement of an individual of the Naranjo court in the affairs of Cahal Pech (Helmke and Awe 2008: 80-82, Fig. 14).
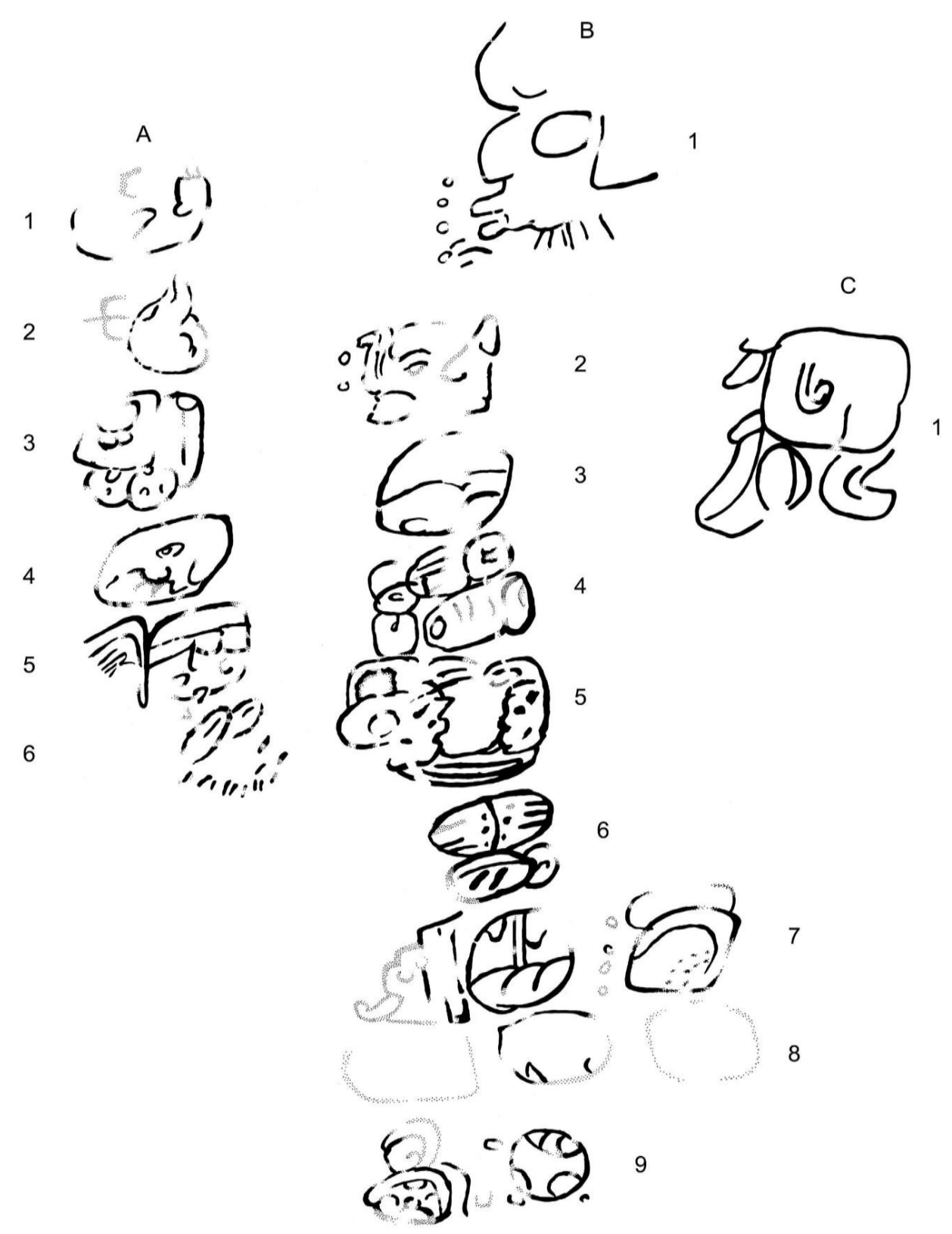

Figure 11: Cahal Pech, Str. A-1, Room 2, lengthy glyphic graffiti incised above the main throne (drawing by C. Helmke, after Helmke and Awe 2008: Fig. 14). 


\section{Conclusions}

As has been touched upon at the onset, the number of glyphic graffiti in the Maya area is very low when compared to other well studied ancient civilizations of the Old World where most graffiti are in fact inscriptional and not figural depictions as in the case of pre-Columbian Maya (e.g. Baird and Taylor 2011; Edwards 2006; LevinRichardson 2019: 40-63; Navrátilová 2007; Peden 2001; Tanzer 1939). This observation leads us to the question of the degree of literacy among the ancient Maya which seems to be a very low when compared to many other early civilizations (cf. Houston 1994: 39; Źrałka 2014: 139). As a modest estimate, assuming that most courtiers were literate, but the remainder of the population was not, this would imply that less than $10 \%$ of the population of a given city-state could read or write (see Inomata and Houston 2001). This observation is supported by the disappearance of glyphic graffiti altogether during the Postclassic, after the Classic Maya collapse. Based on the corpus that we have studied, we can see that the first glyphic graffiti appear during the final part of the Preclassic period, with the Holtun example being so far the oldest graffiti of this type. Their number significantly increases during the Classic, and especially the Late Classic, the period to which we can date most of the glyphic texts identified to date.

With regards to authorship, we can note that the autographs that can be read, for Tikal at least, are all those of the highest royalty, for exalted members of the court and for artisans in the service of the crown. This is rather telling concerning the authorship of the glyphs, given the limited access to these architectural spaces and the possible authorship of many of the figurative graffiti in contextual proximity. Thus, far from folk art as graffiti has often been labelled, when present in palatial complexes and contemporaneous with the use of such complexes, these are likely to have been executed by members of the court itself, rather than being secondary additions in times of collapse, or by squatters in decades after the abandonment of sites. The co-occurrence of some of the highest titles in confined palatial complexes suggest that the glyphic graffiti are often the testimony of the individuals living and working in these structures, and from this we might be able to generalize to other non-regal structures. In one case at Tikal (Str. 5C-49) we should remark that all documented graffiti consist of glyphic texts, which leads us to think that the building was a place where individuals performed scribal activities. In this respect, the structure may be comparable in function to that documented at Xultun (Saturno et 
al. 2017) and to that at Xunantunich on the flanks of the Castillo (McCurdy and Brown in press). The presence of calendrical notations as well as numerical arrays, serving as references for calendrical computations at Nakum, Tikal, Holtun, and Xultun, and the tally of days at Naranjo, coupled with the titular references to ritual specialists at both Naranjo and Xunantunich, reveal that much of the glyphic graffiti are the product of day keepers who lived and worked within the palatial contexts at these important sites.

The existing corpus of hieroglyphic graffiti, although distinctively small, indicates that most texts were rendered by literate individuals, or in some cases semi-literate individuals, since they consist for the most part of viable clauses. Much of the detriment to the analyses of glyphic graffiti is in fact brought about by modern documentation standards, something that we hope can be reversed in the future. Most probably, these glyphic graffiti can be interpreted as personal expressions and notations of calendrical computations, as many examples consist of dates of immediate and synchronic significance, calendrical counts, as well as personal names and the titles of important individuals. Given these observations, we can conclude that these texts constitute intimate records, memorialising presence, residence and use of particular sites, structures and locations of the built environment, as well as a personal wish to leave an imprint of the moment.

Acknowledgements: First and foremost, we would like to thank Rosamund Fitzmaurice, Tia Watkins and Yannis Nakas for their kind invitation to include this piece of research in the present volume. In addition, we are also thankful to the two reviewers of this chapter, as their comments and observations have greatly benefitted our paper. With regards to the graffiti of Tikal we wish to thank Bernard Hermes and Sergei Vepretskii for sharing photos and clarifying details of the graffiti of Group G at Tikal. The senior author would also to thank Jaime Awe and Tia Watkins as well as Kathryn Brown and Leah McCurdy for inviting me to document and study the graffiti of Xunantunich. Finally, we would also like to acknowledge Vilma Fialko, Alexandre Tokovinine, Sergey Kaldov, Graciela Ricci, Michael Callaghan, Brigitte Kovacevich, Mary Clarke, Milan Kováč, and Rogelio Valencia Rivera for sharing with us their drawings and photographs. 


\section{REFERENCES}

Aragón, P 2015 Registro Pictográfico en el Grupo 5E-11 (Grupo G), in Beliaev D and de León M (eds.) Proyecto Atlas Epigráfico de Petén, Fase II: 103-126. Guatemala City: Centro de Estudios Mayas Yuri Knósorov.

Baird, J A and Taylor C (eds.) 2011 Ancient Graffiti in Context. New York: Routledge.

Bates, L 2014 Bombing, Tagging, Writing: An Analysis of the Significance of Graffiti and Street Art. Unpublished MA thesis. Philadelphia: University of Pennsylvania.

Blom, F 1928 San Clemente ruins, Peten (Guatemala). Journal de la Société des Américanistes 20: 93-102.

Boot, E 2013 A "New” Hieroglyphic text at Chichen Itza, Yucatan, Mexico. Mexicon 35(6): 132-4.

Bricker, V, Aveni, A and Bricker, H 2014 Deciphering the Handwriting on the Wall: Some Astronomical Interpretations of the Recent Discoveries at Xultun, Guatemala. Latin American Antiquity 25(2): 152-69.

Callaghan, M G, Kovacevich B, Cardona Caravantes K J, Guzmán Piedrasanta M R, Crawford D and Clarke M 2017 La comunidad preclásica en Holtún, Guatemala: La vista del Grupo F, in Arroyo B, Méndez Salinas L, and Ajú Álvarez G (eds.) XXX Simposio de Investigaciones Arqueológicas en Guatemala, Tomo 1,93-106. Guatemala: Asociación Tikal.

Calvin, I 2006 Between Text and Image: An Analysis of Pseudo-glyphs on Late Classic Maya Pottery from Guatemala. PhD dissertation. Boulder: Department of Anthropology, University of Colorado.

Cardona Caravantes, K J, Callaghan M G, and Kovacevich B (eds.) 2017 Informe No. 6, Temporada 2016: Sitio Arqueológico Holtun, Aldea La Máquina, Flores, Petén. Report submitted to the Instituto de Antropología e Historia de Guatemala, Guatemala City.

Edwards, P 2006 Subscripts: Reading Cambodian Pasts, Presents, and Futures through Graffiti, in Leakthina Chan-Pech $\mathrm{O}$ and Winter T (eds.) Expressions of Cambodia: The Politics of Tradition, Identity, and Change: 23-36. New York: Routledge.

Helmke, C 2009 Ancient Maya Cave Usage as Attested in the Glyphic Corpus of the Maya Lowlands and the Caves of the Roaring Creek. Valley, Belize. Unpublished PhD thesis. 
London: Institute of Archaeology, University of London.

Helmke, C 2020 Tactics, Trophies, and Titles: A Comparative Perspective on Ancient Maya Raiding. Ancient Mesoamerica 31(1): 29-46.

Helmke, C and Awe J. 2008 Organización territorial de los antiguos mayas de Belice Central: confluencia de datos arqueológicos y epigráficos. Mayab 20: 65-91.

Hermes, B, Olko J, and Źrałka J. 2001 En los confines del arte. Los graffiti de Nakum (Peten, Guatemala) y su contexto arquitectónico, arqueológico e iconográfico. Anales del Instituto de Investigaciones Estéticas 79: 29-69.

Houston, S 2018 A "Lost City" in the Heartland. Maya Decipherment. https://mavadecipherment.com/2018/08/27/a-lost-city-in-the-heartland/

Inomata, T and Houston S (eds.) 2001 Royal Courts of the Ancient Maya, Volume I: Theory, Comparison, and Synthesis. Boulder: Westview Press.

Kampen, T 1978 The graffiti of Tikal, Guatemala. Estudios de Cultura Maya 6: 15580.

Kováč, M 2013 Excavaciones e iconografía de la Estructura PM I-sub "La Casa de las Pinturas" (Operación TZB 3), in M. Kováč and E. Arredondo Leiva (eds.) Excavaciones en el Peten Noreste II. Tz'ibatnah y Cb'anal: Temporadas 2011 y 2012: 23-76. Bratislava: Slovak Archaeological and Historical Institute.

Lang, M 1974 Graffiti in the Athenian Agora. Princeton: American School of Classical Studies at Athens.

Levin-Richardson, S 2019 The Brothel of Pompeii: Sex, Class, and Gender at the Margins of Roman Society. Cambridge: Cambridge University Press.

Martin, S and Grube N. 2000. Chronicle of the Maya Kings and Queens: Deciphering the Dynasties of the Ancient Maya. London: Thames and Hudson.

MacLeod, B and Stone A 1995 The Hieroglyphic Inscriptions of Naj Tunich, in Stone A (ed.) Images from the Underworld: Naj Tunich and the Tradition of Maya Cave Painting: 155-184. Austin: University of Texas Press.

Martin, S 2012 Hieroglyphs from the Painted Pyramid: The Epigraphy of Chiik Nahb Structure Sub 1-4, Calakmul, Mexico. Maya Archaeology 2: 60-81.

Mayer, K H 2009 Ancient Maya Architectural Graffiti, in Vidal C and Muñoz G (eds.) Los grafitos mayas: 14-27. Valencia: Ediciones UPV. 
McCurdy, L and Brown M K In Press Sages at Xunantunich: Ancient Maya Scribal Pedagogy and Artistic Training. Telling Time, Myth, History and Everyday Life in the Ancient Maya World. Santa Fe: Sante Fe Institute.

McCurdy, L, Brown M K and Dixon N 2018 Tagged Walls: The Discovery of Ancient Maya Graffiti at El Castillo, Xunantunich. Research Reports in Belizean Archaeology 15: 181-93.

Navarro-Castillo, M, Sheseña A and Pincemin S 2018. The Maya graffiti of Plan de Ayutla, Chiapas. Latin American Antiquity 29(2): 386-93.

Navrátilová, H 2007 The visitors' graffiti of Dynasties XVIII and XIX in Abusir and Northern Saqqara. Prague: Czech Institute of Egyptology.

Orrego, M and Larios R 1983 Reporte de las investigaciones arqueológicas en el Grupo 5E-11, Tikal. Guatemala City: Instituto de Antropología e Historia.

Patrois, J 2013 Río Bec graffiti: A private form of art. Ancient Mesoamerica 24(2): 43347.

Patrois, J and Nondédéo P 2009 Los grafitos mayas prehispánicos en la región de Río Bec (Campeche, México), in C. Vidal and G. Muñoz (eds.) Los grafitos mayas: 29-59. Valencia: Ediciones UPV.

Peden, A 2001 The Graffiti of Pharaonic Egypt: Scope and Roles of Informal Writings (c. 3100332 B.C.). Leiden: Brill.

Saturno, W, Rossi F, Stuart D, and Hurst H 2017 A Maya Curia Regis: Evidence for a Hierarchical Specialist Order at Xultun, Guatemala. Ancient Mesoamerica 28(2): 423-40.

Saturno, W, Stuart D, Aveni A, and Rossi F 2012 Ancient Maya Astronomical Tables from Xultun, Guatemala. Science 336(6082): 714-7.

Stone, A 2005 Divine Stalagmites: Speleothems in Maya Caves and Aesthetic Variation in Maya Art, in Heyd T and Clegg J (eds.) Aesthetics and Rock Art: 21533. Ashgate: Aldershot.

Tanzer, H 1939 The Common People of Pompeii: A Study of the Graffiti. Baltimore: The Johns Hopkins Press.

Tokovinine, A and Fialko V 2019 En el cerro de los colibríes: el patrón divino y el paisaje sagrado de la ciudad de Naranjo, in Arroyo B, Méndez L and Ajú Álvarez 
G (eds.) XXXII Simposio de Investigaciones Arqueológicas en Guatemala, 2019: 82538. Guatemala City: Museo Nacional de Arqueología y Etnología.

Trik, H and Kampen M 1983 The Graffiti of Tikal (Tikal Report No. 31). Philadelphia: The University of Pennsylvania Museum.

Vanhove, D 2006 Thorikos: Graffiti, Dipinti, Stamps (Fouilles De Thorikos, no. 3). Peeters Publishers.

Varone, A 2002 Erotica Pompeiana: Love Inscriptions on the Walls of Pompeii (Studia Archaeologica, no. 116). Rome: L'erma di Bretschneider.

Verhoeven, U 2012 The New Kingdom Graffiti in Tomb N13.1: An Overview, in. Kahl J, El-Khadrragy M, Verhoeven U and Kilian A (eds.) Seven Seasons at Asyut: First Results of the Egyptian-German Cooperation in Archaeological Fieldwork: 47-58. Wiesbaden: Harrassowitz Verlag.

Vidal Lorenzo, C and Muñoz Cosme G (eds.) 2009 Los grafitos mayas. Cuadernos de arquitectura y arqueología maya 2. Valencia: Universidad Politécnica de Valencia.

Watkins, T B, Awe J, Helmke C and Fitzmaurice R 2018 Classic Maya Palaces and their Roles within the Greater Ceremonial Center: Results from the 2017 Field Season Xunantunich, Belize, in Ebert C, Hoggarth J and Awe J (eds.) The Belize Valley Archaeological Reconnaissance Project: A Report of the 2017 Field Season: 33356. Waco: Institute of Archaeology, Baylor University.

Webster, H 1963 Tikal Graffiti. Expedition 6(1): 37-47.

Zender, M and Skidmore J. 2012 Unearthing the Heavens: Classic Maya Murals and Astronomical Tables at Xultun, Guatemala. Mesoweb: www.mesoweb.com/reports/Xultun.pdf.

Źrałka, J 2014 Pre-Columbian Maya graffiti: Context, dating and function. Cracow: Alter.

Źrałka, J, Helmke C, Hermes B, and Koszkul W 2018 Incised ceramics from Nakum, Guatemala, in Valde-Nowak P, Sobczyk K, Nowak M and Źrałka J (eds.) Multas per gentes et multa per saecula: 635-45. Cracow: Institute of Archaeology, Jagiellonian University and Alter Publishing House.

Źrałka, J and Hermes B 2009 Los grafitos prehispánicos de los sitios Nakum y Yaxha, Peten, Guatemala. Su contexto arqueológico, iconográfico y cronológico, in Vidal Lorenzo C and Muñoz Cosme G (eds) Los grafitos mayas: 133-58. Valencia: Universidad Politécnica de Valencia. 